Sandra Bosacki*

ORCID: 0000-0001-9583-4582

St. Catherines, ON, Canada

\title{
Silence, Solitude and Social Cognition in Adolescence: Implications for Research and Education
}

\section{Cisza, samotność i poznanie społeczne w okresie dojrzewania. Implikacje dla badań i edukacji}

\begin{abstract}
What are the key issues regarding silence, solitude, and social cognition in young people's lives, and their implications for education and emotional health? To answer such questions, the current paper will explore the question: How do young teens use their ability to understand other's minds and emotions to navigate their relationships with themselves, their peers, and during times of silences and solitude? To address this question, this paper critically examines how mentallisation may help youth to navigate their experiences of solitude and relationships. Examples from recent and ongoing cross-sectional and longitudinal research with adolescents are discussed within the context of education and developmental psychology research. Finally, I discuss how findings from developmental social cognitive research can be applied to the classroom, to help develop innovative strategies that honour,
\end{abstract}

* Prof. Sandra Bosacki, Department of Educational Studies, Brock University, email: sbosacki@brocku.ca. 
respect, and protect the silences in students' lives and their private times spent in solitude.

Keywords: social cognition; emotion; solitude; adolescents; education.

Abstrakt: Jakie są główne zagadnienia związane z ciszą, samotnością oraz społecznym poznaniem w życiu młodych ludzi? Jakie ich implikacje dla edukacji oraz zdrowia emocjonalnego? By odpowiedzieć na te pytania, w niniejszym artykule poddano analizie następującą kwestię: jak młodzi nastolatkowie korzystają ze zdolności rozumienia umysłów i emocji innych osób, aby budować relacje z sobą oraz z rówieśnikami, szczególnie w okresach ciszy i samotności? By podjąć wskazane zagadnienie, krytycznie zbadano, jak mentalizacja może pomóc młodym ludziom w kształtowaniu doświadczeń związanych zarówno z samotnością, jak i z relacjami. Przedyskutowano przykłady z ostatnich i nadal trwających badań adolescentów, przekrojowych oraz podłużnych, ujmując je w badawczym kontekście edukacji oraz psychologii rozwojowej. Wreszcie ukazano, jak pozyskane doniesienia z badań nad rozwojem społeczno-poznawczym odnieść do klasy szkolnej, celem rozwijania innowacyjnych strategii, honorujących i chroniących ciszę w życiu uczniów oraz ich prywatny czas spędzany w samotności.

Slowa kluczowe: poznanie społeczne; emocja; samotność; adolescenci; edukacja.

\section{Introduction}

'I enjoy my time alone.' Fourteen-year-old girl.

(Bosacki, Sitnik, Dutcher \& Talwar, 2018)

Adolescence is a pivotal time in all areas of development, where the two central tasks are to develop a sense of identity, and to form and solidify relationships (Blakemore, 2018; Crocetti, Prati \& Rubini, 2018). Given these two life tasks, how can teachers and researchers encourage 'emerging adolescents' (i.e. children on the cusp of adolescence) to develop adaptive social-cognitive and emotional skills that will help them navigate times of silences, solitude, and social connections? What are the key issues regarding silence, solitude, and social cognition in young people's lives, and their implications for education and emotional health? Specifically, in this paper I explore the question: How do young teens use their ability to understand 
others' minds and emotions to navigate their relationships with themselves, their peers, and times of silences and solitude? To address this question, I critically examine research on young adolescents' ability to understand mind, emotion, and spirit within their private and public worlds, and how they use this ability to help them navigate their experiences of solitude and their relationships.

These questions and others are discussed within the context of education and with reference to sectional and longitudinal research with Canadian adolescents. Finally, I will discuss how teachers and researchers can apply findings from developmental social cognitive research in the classroom, and develop innovative strategies that honour, respect, and protect the silences in students' lives, and their private times spent in solitude. Overall, this paper explores the question: Given that the overarching aim of education is to nurture and improve the moral, emotional, social, and spiritual lives of youth, exactly how can we help young people grow?

\section{Definitions - what is silence?}

Although the word 'silence' is ubiquitous and often found throughout many educational and psychological literatures, silence is often defined as a prerequisite for reflection, and an integral part of the creative process that entails a fluid loop between reflection and practice. Throughout this paper, I focus on silence as a form of communication, and as an integral part of the teenager's sociolinguistic repertoire that is learned mainly at home and also within the school setting. The 'art of conversation' entails a sociolinguistic repertoire of practice which allows us to learn and practise sociolinguistic behaviours; these are guided by social and cultural conventions which govern appropriate verbal interaction. The art of conversation thus entails both the act of speaking and listening.

As Berryman (2001) suggests, silence may communicate as a call, but it involves no sound. That is, silence can signal and communicate with others, but does not offer any vocalisation. Silence can signal, as well as sound calls. Given the ambiguity of the language used to refer to silence, in numerous languages, there is a cluster or words which refer to communication without sound. In English, they are 'stillness', 'silence' and 'quiet'. All three must be considered in the interpretation of silence, because no single one contains all that is meant by the whole. Overall, the main task of this paper is to depict the complexity of adolescents' experiences of silence within the classroom. 


\section{Definitions: What is social cognition?}

Social cognition is defined as the ability to use one's cognitive and emotional skills to help make sense of, and negotiate, social interactions. Skills such as empathy or the ability to 'feel others' (Bloom, 2016, 2017), and perspective-taking, develop over time and become increasingly complex as children enter adolescence. In particular, Theory of Mind (ToM) involves a myriad of social-cognitive abilities that are used to make sense of mental states in oneself and other people, in order to predict actions. In the past 20 years, there has been a surge of interest in the development of Theory of Mind in relation to older children and adolescents (Bosacki et al., 2018); however, few studies explore how teenagers apply ToM skills to experiences of solitude and to relationships (Woodcock, Cheung, Marx \& Mandy, 2019). Given the importance of identity formation and attachment during adolescence (Kaniusonyte, Truskauskaite-Kunevidciene, Zukauskiene \& Crocetti, 2019; Kroger, 2006), adolescents need to learn how to spend time with themselves in solitude, as well as to interact with others in relationships. How, then, can ToM skills help youth to hone their personal skills within solitude, as well as social skills within relationships? In the next sections I will outline research in both areas, within the context of adolescence.

\section{Research: ToM in Relationships with self and other (Solitude and Attachment)}

\section{Research: Silence in Solitude}

Silence can be experienced alone or with others, and can be accompanied by positive and/or negative emotions. Compared to research on the 'simple' or primary and basic emotions (i.e. emotions linked to underlying physiology) such as happy and sad, complex or moral or self-conscious emotions that involve the ability to self-evaluate against internalised standards of behaviour, such as pride and shame, receive less attention (Bosacki, Pissoto-Moreira, Sitnik, Andrews \& Talwar, 2020; Saarni, 1999). Thus, although theoretical links exist among self-conscious emotions, self-cognitions or identity, solitude, and social relations (Bain, 1875; Blote, Miers, Van den Bos \& Westenberg et al., 2019; Hull, Petrides, Allison, Smith, Baron-Cohen, Lai \& Mandy, 2017), little is known about how such a nexus develops in ado- 
lescents (de Hooge, Breugelmans, Wagemans \& Zeelenberg, 2018; Karbach \& Unger, 2014).

Private silences may represent a speaker's decision to abstain from contributing to a conversation, and thus suggest a sense of personal agency or control over the decision (Blote et al., 2019); the decision could be guided by one's own volition, independent of any external forces. Alternatively, an individual may have felt pressured by others to comply to the silence, and thus may feel 'silenced'. Thus, the process of 'silencing' is psychologically and emotionally complex and multifaceted.

The decision to remain silent becomes in part social, in that the individual's choice to remain silent in a public forum may have mixed positive and negative influences on others (Son \& Padilla-Walker, 2019). For example, within a learning school environment, a child who is called upon in class and chooses to remain silent may challenge the teacher, as the teacher may interpret the silence as a lack of knowledge or effort, caused by either fear or defiance. The silent child singled out in front of their peers might also appear odd to others. In terms of the decision to remain silent among one's peers, this social silence could also be viewed as a prosocial action. That is, this act of social silence can serve as a comforting or emotionally supportive action, as either hugging or listening to a peer may have a positive influence on the friend's well-being (Son \& Padilla-Walker, 2019).

In addition, the mental and social reasoning - or Theory of Mind (ToM) ability - when connected with silence in the classroom, may also create a reaction solicited from the audience; this in turn may create mixed emotional reactions within the child (Nicolic, van der Storm, Colonessi, Brummelman, Kan \& Bogels, 2019; Woodcock et al., 2019). On the one hand, a child who is asked to sit in the class with others for five or ten minutes of 'silence' or 'quiet time' may experience positive emotions, as this task provides the opportunity to remain silent, reflect, contemplate, and to listen to their inner voice and expand their imagination. Thus, such times of silence and solitude have the potential to give adolescents the opportunity to exercise their imaginative and creative abilities by listening to both mental and physical messages from within. Alternatively, being asked to sit in silence by an authority figure may also induce negative feelings such as shame, embarrassment and guilt, as well as negative ruminations over the young person's experience of silence.

The ambiguous nature of the experience of silence leads to multiple interpretations, in that two people may interpret the same event differently. To illustrate such ambiguous interpretations, on a personal note, when I was 
seven years old, during art class one school day, my Grade 2 teacher ordered me to spend time alone in the classroom closet. I had failed to follow instructions in our art class, and instead of painting what the teacher had asked, I took the liberty of creating my own rules, and continued to paint a different scene. My teacher ordered me to be sent to a five-minute 'time-out' of quiet and solitude in the classroom cloak closet.

In this case, my teacher might have expected my 'time out in the closet' to serve as a disciplinary action. That is, my teacher might have intended that this 'time-out' or solitary confinement away from my peers was meant to provide me with a quiet time of solitude, in which to reflect on how I had failed to follow class rules, and how as a consequence of my actions, I was ordered to be in a closet by myself. In contrast, in my view, it was an opportunity to imagine myself outside of the classroom on some beach holiday instead. Both cases, of either self- or other-initiated silence, as defined by a lack of verbal expression, provide an opportunity for an individual to listen to her or his thoughts, emotions and physical sensations; which in turn may have either positive or negative influences on a child's sense of self-confidence and competence.

Similar to academic experiences, within the school context, social situations also include experiences of silence, and such experiences may either ameliorate or exacerbate the young person's sense of social competence and confidence (Kaniusonyte et al., 2019; Spence \& Rapee, 2016). According to a psychocultural approach to personal experiences of silence (Bronfenbrenner, 1986; Fivush, 2019), in order to decide if one talks or remains silent, one first identifies which resources (experiential, cognitive, affective, linguistic, etc.) are most useful to one's self in a social world (Bronfenbrenner, 1986). Regarding the process of silence and speech, the question remains: How do adolescents learn to satisfy their social and emotional needs enough to develop curiosity and avoid boredom (Berlyne, 1966; Engel, 2011, 2015), and to participate effectively across diverse social contexts (Jiang, Jiang, Du, Gu, Sun \& Zhang, 2019)?

In other words, how does self-knowledge emerge out of social experiences in different pragmatic circumstances during adolescence? This psychocultural approach assumes that the abstract knowledge (e.g. ToM) is built out of experiential, pragmatic knowledge acquired in an interpreted, social world (Bruner, 1996). Such a developmental view of psychological understanding supports further research of scholars who explore the connections between thought, language and behaviour within the social world across cultures (Kuhn, 2019; Taumoepeau, Sadeghi \& Nobilo, 2019). For example, in 
the case of social avoidance and social anxiety, silence is often connected with negative social experiences, self-cognitions, and emotions (Blote et al., 2019). Silences may thus carry different psychological meanings which represent different motivations underlying the silence.

These experiences of silence may be especially pronounced during social group situations, where verbal expression is often equated with confidence, popularity and social status. Such situations occur frequently during adolescence, when a teen who holds psychological power over her peer in the social hierarchy chooses to harass or psychologically damage her peer, giving her a lower social status by choosing to not speak to her. Hence, a popular adolescent who develops an advanced ToM ability may choose to use this information to harm others, and thus decide to either neglect or reject their peers - by either not speaking, or ignoring any requests or attempts for interaction (Fenigstein, 1979; Nicolic et al., 2019). This 'silent treatment', or acting as though someone is invisible, is often considered a form of psychological or emotional harassment if the adolescent on the receiving end is hurt emotionally, as the silence may be interpreted as a sign of rejection.

Alternatively, adolescents who find it stressful to join social groups, or who are painfully shy, may choose to remain silent in a group situation to remain safe, and to avoid the negative feelings that may arise from the possible rejection (Woodcock et al., 2019). That is, an adolescent may wish to say something to another peer, but the thought of rejection, social evaluation, and/or ridicule may prevent her from taking the risk of expressing her thoughts. Thus, if she then wishes to contribute but cannot due to fear of judgement or evaluation by others, she may decide to either remain silent, or withdraw from the social situation to avoid negative feelings such as anxiety and/or irritation (Eggum-Wilkens, Danming, Zhang \& Costa, 2020).

Others may also choose to remain silent because they enjoy their time alone, in the classroom, in solitary play, walking alone in outdoors during school recess, or choosing to remain uninterested or disengaged. Recent studies on adolescents who prefer solitude to being with others find that some may lack the motivation to approach others, while at the same time, may not necessarily have the motivation to avoid others (Danneel, Maes, Vanhalst, Bijttebier \& Goossens, 2018). Thus, when such individuals are approached by others they will not remain reticent and retreat, and may not experience wariness and anxiety (Schmidt \& Poole, 2019; Coplan, Ooi \& Baldwin, 2019).

Finally, in situations in which adolescents feel unsafe and fearful, silence can be used in a tactical or strategic way as a source of self-protection. 
This safe silence conceals as it communicates, and can hide an adolescent's anger behind a mask whose meaning he can quickly change if necessary (Bosacki, 2013). For example, findings from our interviews with Canadian 11 to 13-year-old girls and boys showed that adolescents who remained silent and refrained from engaging in social conversations often felt upset, anxious or stressed. Silence, then, may send mixed and ambiguous messages to others (Bischetti, Ceccato, Lecce, Cavallini \& Bambini, 2019; Jara-Ettinger, Floyd, Huey, Tenebaum \& Schulz, 2019). Hence, when contained, silence can be wielded to protect the self. Alternatively, it can be used to create psychological space within relationships, which can help to formulate new directions and offer possibilities for change. Thus, hostile silences, controlling silences, resisting silences, political silences, and safe silences can enhance possibilities for creating change in the self and others.

In sum, silence is complicated in that it has psychological benefits as well as costs. That is, for some individuals, silence may be viewed as a source of inspiration and self-exploration, and a time for quiet reflection and contemplation (Goossens \& Marcoen, 1999). However, for others, silence may be accompanied by loneliness and emotional pain. The latter vision of silence may thus bring wariness in social company, victimisation, fear of rejection, and feelings of loneliness (need for social connections) and aloneliness (need for solitude) (Coplan et al., 2019; Galanaki, 2004). In short, there are multiple underlying motivations for behavioural expressions of silence among adolescents, many of which remain unknown. Given such complexity regarding adolescents' motivations for silence and solitude, further investigation is needed (Eggum-Wilkens et al., 2020).

\section{Research: Silence within Relationships}

Adolescents' ability to communicate effectively with others depends partly upon knowledge and skills that have little or nothing to do with language per se. For example, children learn that they may have to greet others and to end a conversation with some form of a sign-off. The social conventions that govern appropriate verbal interaction are called sociolinguistics or pragmatics, and continue to develop in complexity during adolescence. Such behaviours include the understanding and performance of rules of conversational etiquette - taking turns in conversations, such as saying goodbye when leaving, and so on. Social pragmatics also includes strategies for understanding the subtleties of ambiguous and non-literal or figurative lan- 
guage, such as humour (Bischetti et al., 2019); metaphor, irony, and sarcasm (Grice, 1975; Jara-Ettinger et al., 2019); and the ability to initiate conversations, change subjects, share stories, and argue persuasively.

Beginning at around two to three years of age (Pouscoulous \& Tomasello, 2019), children continue to refine their pragmatic skills and sociolinguistic conventions throughout the preschool years, into adolescence and adulthood. However, this development is affected by cultural differences, as languages often follow varying and distinct conventions, particularly in the areas of social etiquette, social rules and conventions. That is, adolescents consider not just what other people see and know, but also how people are likely to behave in different contexts, based on the costs different plans impose on different agents. Such an understanding may, in turn, help them build more nuanced theories of other people's behaviour, and further develop their Theory of Mind or the ability to mentalise (Jara-Ettinger et al., 2019).

As mentioned earlier, silence is ambiguous in that it can be experienced in solitude or with others, and can be accompanied by mixed emotions. Within close friendships, silence can be felt in terms of feelings of loneliness. For instance, recent studies suggest that despite having an existing best friendship, some adolescents experience loneliness (Nowland, Balmer \& Qualter, 2019) and silence in terms of sadness. Such feelings of silence are in contrast to young people who claim to experience feelings of peace and comfort during silences within their close friendships (Parker \& Asher, 1993). Given the diversity of such experienced silences, those who experience sad silences may need support to form high-quality friendships and reduce their loneliness (Nowland et al., 2019).

To describe feelings of being silenced by others within relationships, versus choosing to remain silent among others (i.e. self-silence), Goldberger, Tarule, Clinchyand and Belenky's notion (1986) describes two types of silences: structural and strategic. Structural silence is due to societal rules that dictate when individuals should speak or be silent, and may lead to negative feelings. Thus, such structural silence drives some people to a defensive stance of silence and passivity, which stems from feelings of fear and threat. In contrast to this structural silence in which an individual has either little or no control, strategic silence is when an individual makes the decision to be silent. Situational and cultural factors can dictate individual strategic silence, in which the individual deliberately chooses to be silent and yet remains able to engage in conversations as an active, contributing knower.

Structural and strategic silences play important roles within an adolescent's personal and social worlds. In the case of structural silence, an ado- 
lescent may either feel 'silenced' due to lack of knowledge of a particular emotion word, or may feel silenced by the 'other' who does not allow them to speak. Such a lack of communication, or this disconnect, may lead the adolescent to feel silenced and unable to speak. Thus, structural silence is dependent upon social situations and interpersonal interactions.

In contrast to structural silence, in strategic silence, irrespective of external forces, an adolescent may choose not to express a specific emotion, or to articulate a specific emotion label. Thus, strategic silences are mostly self-motivated and regulated. Given these differences, what then are the emotional implications of self-imposed or strategic, versus authoritative or structural, codes of silence? Given that the experiences of such silences are personal in nature, and the motivations for self-silence may be influenced by social interactions, ultimately the decision to remain silent remains at a private, subjective level (Nguyen, Werner \& Soenens, 2019).

During adolescence, constructive uses of solitude can include silences as a means of power, reflection, and self-expression (Zavala \& Kuhn, 2017). In addition to spending time in silence during periods of solitude, silence can also be used as a particular method in large group situations such as schools. As vocalisation is often connected to issues of power within the classroom, some students who often speak out may feel more powerful than others, and are thus more likely to use silence as a tool to convey this power (Blote et al., 2019; Jara-Ettinger et al., 2019).

Literacy involves critical and reflective thinking and functioning, or mentalisation, through the social event of discourse and dialogue (Zavala \& Kuhn, 2017). Such a relational event helps to promote inquiry and argumentation that constructs social identities, positions adolescents amongst their peer group, and demarcates social boundaries between adults and adolescents (Kuhn \& Crowell, 2011). Findings from our ongoing studies illustrate young adolescents' awareness of the power of classroom peer dynamics, and how their actions have social and emotional consequences (Bosacki et al., 2018). For instance, most adolescents claim to know which of their peers to include, and whom to marginalise within the peer group to gain status or power in the classroom (i.e. popularity).

Studies suggest that children as young as four and five years old are capable of analysing their social gains by conducting a cost/benefit analysis (Jara-Ettinger et al., 2019). Hence, some children may draw on social knowledge for personal benefit and raise their status within the social hierarchy of the classroom. Other studies with older children illustrate how some young people may decide to use silence as opposed to articulation, to exert 
power and control over others (Woodcock et al., 2019). For example, one may choose to not speak to - or to ignore - another peer due to the peer's lower social status (e.g. they are unpopular). As a result, the lower-status peer is often treated as invisible or unworthy of communication. However, some decide to use their social knowledge to help others, as was seen in our longitudinal research with Canadian adolescents (Bosacki, Moriera, Sitnik, Andrews \& Talwar, 2019). In response to the question 'What makes you different from others in your class?', a 15-year-old girl stated that 'a lot of kids are really quiet and I'm really helpful and help them to become more confident and bring them into this world.'

In contrast to prosocial silences, silences may also send another message, of alienation, despair and hopelessness. That is, aggressive or belligerent silence can prevent confrontation and anger in relationships. Aggressive silence often fails to bridge social connections to others that could lead to dialogue, reconciliation, or new relational patterns. The hostility vented through such silences also holds the potential to affect others negatively. Given that silence may send mixed and ambiguous messages to others, it may communicate anger but contradicts the anger's call for a response. Aggressive silence also suggests an unforgiving and critical harshness toward the self. Such silence is sometimes associated with stress, lack of self-compassion (Bosacki et al., 2018), and other internalising challenges such as anxiety and depression.

In addition, while not intended as aggressive, misinterpreted silences may be just as detrimental to students' mental health. Recent findings from our research suggest how Canadian elementary school teachers' perceptions of children's verbal loudness and silent behaviour may reflect stereotypical gender patterns (Coplan et al., 2019). That is, teachers were more likely to rate quietness and silence in girls as positive, and loudness or exuberance as problematic, whereas the opposite pattern was found for boys (i.e. loud boys/silent girls - good; silent boys/loud girls - bad). Similar findings are found in our past research on Canadian adolescents' views of talking and listening with their friends and family members. Results showed that compared to boys, girls were more likely to report that silence was often more effective in social relationships than talking, as many felt ignored or silenced when they did speak (Bosacki, 2013).

Gender differences in social cognition and experiences of silence, then, may exert an indirect influence on the development of social-cognitive and communicative differences in children's stereotypical gender-role ascriptions, such as femininity and masculinity abilities (Bosacki, 2013; Bosacki 
et al., 2018), as opposed to differences in biological sex. Thus, guided by their own emotional scripts that have been co-constructed through social interactions with their parents and others (e.g. siblings, peers, teachers), adolescents' social and emotional competencies may reflect gender-role stereotypes, resulting in observable gender differences (Bosacki et al., 2018). Hence, the process of learning to understand emotions within a social context may not be contingent solely on whether a child is female or male, but on the way in which a child's gender interacts with her/his environment.

\section{So What? Educational Implications: How can schools 'cultivate curiosity'?}

The connections among emotional development and language - including silence - are complex, and have strong implications for the educational context, particularly the secondary-school classroom. Many emotion researchers note that sometimes the expression of emotion is contingent upon a particular label or emotion word. Thus, building on Goldberger and colleagues' (1986) notion of structural and strategic silence, both types of silence may have different emotional implications. That is, structural silence experienced within relationships may be accompanied by feelings of shame and guilt or sadness, whereas strategic silence may be connected with feelings of peace and satisfaction, as this is the personal choice of the one who is silent.

Regarding the subtleties of perceived social interactions and solitude, researchers also remain challenged by the question of how adolescents learn to understand the mental states and emotions of others, and how this influences their sense of self-worth and preferences for socialisation and solitude. To help understand how adolescents co-construct their knowledge of others based on their social experiences, advocacy research helps to illustrate how socio-political structures affect the sociocultural construction of knowledge and consciousness (Seider, Clark \& Graves, 2019). Given that critical analysis offers a way of analysing different strands of thinking, such as academic, social, emotional, and moral (Seider et al., 2019), this paper in part applies an analytical lens to help define the role curiosity plays within the area of psychosocial pragmatics, or what we do with language to relate to others (Grice, 1975). More specifically, in the following section I build on studies that suggest curiosity drives engagement and well-being (Hulme, Green \& Ladd, 2013; Kashdan \& Steger, 2007). 
A culture or climate of mutual respect, courage, compassion, curiosity and sensitivity is one that helps promote prosocial attitudes and behaviours, including acceptance of and respect for differences. The tacit and explicit social norms and rules, that govern sociolinguistic behaviours in the school setting, define what is acceptable and unacceptable treatment of individuals. Given that school life affects all aspects of human development, and because our world is becoming increasingly global and diverse, children are likely to interact with others whose race, ethnicity and family backgrounds differ from their own (Seider et al., 2015). In addition to race and ethnicity, other differences such as gender, social class, physical characteristics and sexual orientation may serve as focal points for conflict and intolerance among adolescents. As past researchers suggest, there is a need for the creation and implementation of gender and culturally sensitive, developmentally appropriate curricula that promote tolerance and respect for differences among students, in this increasingly multi-ethnic, multi-faith and democratic society (Surette, 2019).

The school culture or climate also represents the nature of the interpersonal relationships (student-student, student-teacher, teacher-teacher/parent) that exist in the school, and how involved parents are in the daily activities and decision-making processes in the school. The emotional or psychological tone set in the school establishes expectations for standards of interpersonal relationships among the students beyond school walls as well. That is, to promote a larger culture of empathy and compassion, the classroom and school need to reflect the larger community (and vice versa). Furthermore, educators and researchers are called to address emerging tensions between ethnic and school/academic identities in educational practice (Taumoepeau et al., 2019).

To address the need to promote acceptance and respect for self and others, and overall mental health, multiple holistic educational programmes now aim to promote adolescents' learning, and to transcend status variables such as ethnicity, social class and gender (Okano, Jeon, Crandall \& Riley, 2019). For example, one holistic educational programme developed by Jiang et al. (2019) follows a cognitive, emotional and behavioural framework (CEB). Drawing on psychocultural principles of development, this programme promotes tolerance of differences by understanding the developmental contributions to attitudes towards others who are different; this is achieved through examining the cognitive, emotional and behavioural ways in which these attitudes are expressed. The cognitive component refers to knowledge, expectations and beliefs about others; the emotional component refers to chil- 
dren's affective reactions; and the behavioural component includes the observable actions towards others who are different. This is done by examining the cognitive, emotional and behavioural ways in which these attitudes are expressed.

In addition, one of the most widely accepted notions of peace education reform in North America is the school conflict educational strategy of peer mediation and mindfulness programmes (Priniski, Hecht \& Harackiewicz, 2018). Such programmes encourage students to manage conflicts constructively using negotiation procedures, including leadership and peace-making skills. Key features of these programmes include the development of models that promote conflict mediation, peaceful, non-violent leadership, and respect for differences. These programmes build on foundational skills such as critical inquiry, critical thinking as dialogue and argumentation (Kuhn, 2019), reflective or contemplative functioning, curiosity, and prosocial action (Engel, 2011, 2015).

Regarding practical tools for educators, further exploration of various experiences of silences and their socio-emotional and spiritual consequences suggests the need for useful assessment tools and interventions. Drawing on research that shows links between psychological and spiritual understanding and positive school experiences (Bosacki et al., 2019), we can teach a 'psychological language' to adolescents that focuses on self-reflection, self-compassion and self-acceptance (Bosacki et al., 2020). As educators, we can encourage children to develop a mental-state vocabulary of the self and others (Bruner, 1996). Such initiatives support researchers and educators who advocate the importance of narrative, emotion and metacognition in education (Fivush, 2019; Hughes, 2011).

Curriculum development that utilises narrative may thus enhance adolescents' ability to understand self and other in a psychological sense. Fiction books that describe people's psycho-emotional worlds can be used in the classroom to improve critical consciousness, and curiosity (Seider et al., 2019). For instance, excerpts that encourage adolescents' reflection, from Sylvia Plath's (1996) The It-Doesn 't-Matter Suit, Judy Blume's (1972) Blubber, and Margaret Atwood's (1988) Cat's Eye, could be used to illustrate the landscape of adolescents' private worlds and inner voices. Moreover, consistent with work in positive youth psychology (Seligman, 2002), as well as our past and ongoing work on adolescents' psychosocial development and mental health (Bosacki, 2002; Bosacki et al., 2020), future research in this area may provide a framework for a holistic curriculum that aims to foster both inter- and intrapersonal competencies. 
Such programmes may help children and adolescents to develop into courageous, curious, competent, compassionate and caring adults who are both experts in their chosen careers and socially responsible. As the 21 st century becomes increasingly complex and technologically advanced, educators and researchers need to take the time to be critical of the programmes, and to examine the gaps and silences, in order to promote ideal connections among ethics, excellence, culture and cognition.

In sum, through the integration of ideas from developmental cognitive psychology (e.g. metacognitive activities such as social problem solving and critical dialogue) (Kuhn, 2019; Pennequin, Questel, Dalaville, Delugre \& Maintenant, 2019), and holistic curriculum models (e.g. art-based activities such as role-playing, autobiographical writing and painting, creative writing, drawing, music, and dance), multidisciplinary psycho-educational programmes can make a valuable contribution to secondary-school curricula. Such comprehensive educational programmes could be used to help balance the distribution of affective and cognitive, as well as metacognitive activities within classrooms.

\section{Future Questions and Directions}

In summary, this paper has presented an overview of research on silence, social cognition and social relations in adolescence. However, the aforementioned studies do not specifically address the possibility that 1) a developmental constructivist theoretical framework may help to explain individual differences found among language, social-cognitive abilities and social relations; 2) that self-cognitions may play an intervening role between social cognition, experiences of silence and solitude, and social relations; and 3 ) that gender and culture-related linkages and differences may occur between experiences of silence and solitude, social cognition, and social relations. Future studies, including our ongoing work, need to explore such complex questions.

Building on past literature (Blakemore, 2018; Bosacki, 2016), most typically, developing adolescent minds are capable of social cognitive skills such as mentalisation, including metacognition (the ability to think about thinking) (Efklides, 2011; Flavell, 1979), self-cognitions, and social-relational skills (Nicolic et al., 2019). This paper has aimed to show how experiences of silence during adolescence may influence young people's sense of self, relationships, and overall well-being. Through the integration of ideas 
from cognitive psychology (metacognitive activities) and holistic curriculum models (art-based activities) that promote collaborative learning as well as contemplation and reflection, such a programme may provide a valuable contribution to adolescent education.

Programmes that integrate cognitive psychology through the use of metacognitive activities will encourage students to be active participants in the construction of knowledge and making meaning. To reach this goal, the fields of psychology and education need to work together to promote a community of curiosity and enquiry that addresses the definition of human nature and promotes critical curiosity, constructive solitude, and prosocial action (Son \& Padilla-Walker, 2019; Vracheva, Moussetis \& Abu-Rahma, 2019). In collaboration with social conversations, one's private, internal dialogue strengthens one's connections to self, community and beyond (Zavala \& Kuhn, 2017). Such openness and connection is necessary if we are to listen to and learn from children and youth.

In short, a future vision for research on the psychosocial implications of silence in adolescence includes educators and researchers who work and care about youth. All youth leaders need to share a common goal to awaken adolescents' curiosity and appetite for learning and life. We cannot allow today's youth to become disengaged from others around them, or bored with life.

\section{References}

Bain, A. (1875). The emotions and the will. London: Parke.

Berlyne, D. E. (1966). Curiosity and exploration. Science, 153(3731), 25-33.

Berryman, J. (2001). The nonverbal nature of spirituality and religious language. In J. Erricker, C. Ota \& C. Erricker (eds.), Spiritual education: Cultural, religious, and social differences: New perspectives for the 21 $1^{\text {st }}$ century (pp. 9-33). Brighton, UK: Sussex Academic Press.

Bischetti, L., Ceccato, I., Lecce, S., Cavallini, E. \& Bambini, V. (2019). Pragmatics and theory of mind in older adults' humor comprehension. Current Psychology. https://doi.org/10.1007/s12144-019-00295-w

Blakemore, S.-J. (2018). Inventing ourselves: The secret life of the teenage brain. New York: Doubleday.

Bloom, P. (2016). Against empathy: The case for rational compassion. Harper Collins: New York.

Bloom, P. (2017). Empathy and its discontents. Trends in Cognitive Sciences, 21(1), 24-31. 
Blote, A., Miers, A., Van den Bos, E. \& Westenberg, M. (2019). Negative self-cognitions: How shyness may lead to social anxiety. Journal of Applied Developmental Psychology, 26, 9-15.

Bosacki, S. (2002). Spirituality and self in preadolescents: Implications for a connected curriculum. Journal of Beliefs and Values: Studies in Religion and Education, 23, 55-67.

Bosacki, S. (2013). Theory of mind understanding and conversational patterns in early adolescence. Journal of Genetic Psychology, 174, 170-191.

Bosacki, S. (2015). Children's theory of mind, self-perceptions, and peer relations: A longitudinal study. Infant and Child Development, 24, 175-188. DOI: 10. 1002/icd.1878

Bosacki, S. (2016). Social cognition in middle childhood and adolescence: Integrating the personal, social, and educational lives of young people. Chichester, UK: Wiley Blackwell.

Bosacki, S., Moriera, F., Sitnik, V., Andrews, K. \& Talwar, V. (2019). Theory of mind, emotion knowledge, and school engagement in emerging adolescents. International Electronic Journal of Elementary Education, 11(5), 529-538.

Bosacki, S., Sitnik, V., Dutcher, K. \& Talwar, V. (2018). Gratefulness, compassion, and ToM in adolescence. Journal of Genetic Psychology, 179(5), 256-269. DOI: 10.1080/00221325.2018.1499607

Bosacki, S., Pissoto-Moreira, F., Sitnik, V., Andrews, K. \& Talwar, V. (2020). Theory of mind, self-knowledge, perceptions of loneliness in emerging adolescents. Journal of Genetic Psychology, 180(1), 14-31. DOI: 10.1080/00221325. 2019.1687418

Bronfenbrenner, U. (1986). Ecology of the family as a context for human development: Research perspectives. Developmental Psychology, 22, 723-742.

Bruner, J. (1996). The of education. Cambridge, MA: Harvard University Press.

Colonnesi, C., Nikolić, M., de Vente, W. \& Bögels, S. M. (2017). Social anxiety symptoms in young children: Investigating the interplay of theory of mind and expressions of shyness. Journal of Abnormal Child Psychology, 45, 997-1011. https://doi.org/10.1007/s10802-016-0206-0

Coplan, R. J., Ooi, L. L. \& Baldwin, D. (2019). Does it matter when we want to be alone? Exploring developmental timing effects in the implications of unsociability. New Ideas in Psychology, 53, 47-57. https://doi.org/10.1016/j.newideapsych.2018.01.001

Crocetti, E., Prati, F. \& Rubini, M. (2018). The interplay of personal and social identity. European Psychologist, 23, 300-310. https://doi.org/10.1027/1016-9040/ a000336 
Danneel, S., Maes, M., Vanhalst, J., Bijttebier, P. \& Goossens, L. (2018). Developmental change in loneliness and attitudes toward aloneness in adolescence. Journal of Youth in Adolescence, 47, 148-161. doi:10.1007/s10964-017-0685-5

de Hooge, I., Breugelmans, S., Wagemans. F. \& Zeelenberg, M. (2018). The social side of shame: approach versus withdrawal. Cognition and Emotion, 32(8), 1671-1677. DOI: 10.1080/02699931.2017.1422696

Deci, E. L. \& Ryan, R. M. (2000). The "what" and "why” of goal pursuits: Human needs and the self-determination of behavior. Psychological Inquiry, 11, 227-268.

Efklides, A. (2011). Interactions of metacognition with motivation and affect in self-regulated learning: The MASRL model. Educational Psychologist, 46(1), 6-25. https://doi.org/10.1080/ 00461520.2011.538645

Eggum-Wilkens, N. D., Danming, A., Zhang, L. \& Costa, M. (2020). Co-occurrence of and cross-informant agreement on shyness, unsociability, and social avoidance during early adolescence. Social Development, 29(1), 73-88. doi: 10.1111/ sode. 12398

Engel, S. (2011). Children's need to know: Curiosity in schools. Harvard Educational Review, 81(4), 627-645.

Engel, S. (2015). The hungry mind: The origins of curiosity in childhood. Cambridge, MA: Harvard University Press.

Fenigstein, A. (1979). Self-consciousness, self-attention, and social interaction. Journal of Personality and Social Psychology, 37, 75-86. https://doi.org/10.1037/ 0022-3514.37.1.75

Fivush, R. (2019). Integration and differentiation of self through reminiscing and narrative. Social Development. doi: 10.1111/sode.12399

Flavell, J. H. (1979). Metacognition and cognitive monitoring: A new area of cognitive developmental inquiry. American Psychologist, 34(10), 906-911.

Galanaki, E. (2004). Are children able to distinguish among the concepts of aloneness, loneliness, and solitude? International Journal of Behavioral Development, 28(5), 435-443.

Goldberger, N., Tarule, J., Clinchy, B. \& Belenky, M. (1986). Knowledge, differences, and powers: Essays inspired by women's ways of knowing. New York: Basic Books.

Goossens, L. \& Marcoen, A. (1999). Adolescent loneliness, self-reflection, and identity: From individual differences to developmental processes. In K. J. Rotenberg \& S. Hymel (eds.), Loneliness in childhood and adolescence (pp. 225-243). New York, NY: Cambridge University Press.

Grice, H. P. (1975). Logic and conversation. New York, NY: Academic Press. https:// doi.org/10.25291/VR/1975-VR-58 
Hughes, C. (2011). Social understanding and social lives: From toddlerhood through to the transition to school. New York, NY: Psychology Press.

Hull, L., Petrides, K. V., Allison, C., Smith, P., Baron-Cohen, S., Lai, M.-C. \& Mandy, W. (2017). "Putting on my best normal": Social camouflaging in adults with autism spectrum conditions. Journal of Autism and Developmental Disorders, 47(8), 2519-2534. https://doi.org/10.1007/s1080 3-017-3166-5.

Hulme, E., Green, D. T. \& Ladd, K. S. (2013). Fostering student engagement by cultivating curiosity. New Directions for Student Services, 143, 53-64.

Jara-Ettinger, J., Floyd, S., Huey, H., Tenebaum, J. \& Schulz, L. (2019). Social pragmatics: Preschoolers rely on commonsense psychology to resolve referential underspecification. Child Development, 1-15. DOI: 10.1111/cdev.13290

Jiang, W., Jiang, J., Du, X., Gu, D., Sun, Y. \& Zhang, Y. (2019). Striving and happiness: Between- and within-person-level associations among grit, needs satisfaction and subjective well-being. The Journal of Positive Psychology. DOI: 10.1080/17439760.2019.1639796

Kaniusonyte, G., Truskauskaite-Kunevidciene, I., Zukauskiene, R. \& Crocettii, E. (2019). Knowing who you are for not feeling lonely? A longitudinal study on identity and loneliness. Child Development. DOI: 10.1111/cdev.13294

Karbach, J. \& Unger, K. (2014). Executive control training from middle childhood to adolescence. Frontiers in Psychology, 5. https://doi.org/10.3389/fpsyg.2014. 00390

Kashdan, T. B. \& Steger, M. F. (2007). Curiosity and pathways to well-being and meaning in life: Traits, states, and everyday behaviors. Motivation and Emotion, 31(3), 159-173.

Kroger, J. (2006). Identity development during adolescence. In G. R. Adams \& M. D. Berzonsky (eds.), Blackwell handbook of adolescence (pp. 205-226). Oxford, UK: Blackwell Publishing Ltd. https://doi.org/10.1002/ 978047075 $6607 . \operatorname{ch} 10$.

Kuhn, D. (2019). Critical thinking as discourse. Human Development, 62, 146-164.

Kuhn, D. \& Crowell, A. (2011). Dialogic argumentation as a vehicle for developing young adolescents' thinking. Psychological Science, 22(4), 545-552. https:// doi.org/10.1177/0956797611402512

Nguyen, T., Werner, K. \& Soenens, B. (2019). Embracing me-time: Motivation for solitude during transition to college. Motivation and Emotion. https://doi.org/ 10.1007/s11031-019-09759-9c

Nicolic, M., van der Storm, L., Colonessi, C., Brummelman, E., Kan, K. \& Bogels, S. (2019). Are socially anxious children poor or advanced mindreaders? Child Development, 90, 1425-1441. 
Nowland, R., Balmer, D. \& Qualter, P. (2019). When friends behave badly: Loneliness and children's expectations of friends and responses to transgressions. British Journal of Developmental Psychology. DOI:10.1111/bjdp.12296

Okano, L., Jeon, L., Crandall, A. \& Riley, A. (2019). Differential effects of internalizing behaviors on academic functioning for girls versus boys: An analysis of developmental cascades from elementary to high school. Development and Psychopathology, 1-14. https://doi.org/10.1017/S0954579419000737

Parker, G. \& Asher, S. (1993). Friendship and friendship quality in middle childhood: Links with peer group acceptance and feelings of loneliness and social dissatisfaction. Developmental Psychology, 2, 611-621. https://doi.org/10.1037 /0012-1649.29.4.611

Pennequin, V., Questel, F., Dalaville, E., Delugre, M. \& Maintenant, C. (2019). Metacognition and emotional regulation in children from 8 to 12 years old. British Journal of Educational Psychology. DOI: 10.1111/bjep.12305

Pouscoulous, N. \& Tomasello, M. (2019). Early birds: Metaphor understanding in 3-year-olds. Journal of Pragmatics, in-press.

Priniski, S. J., Hecht, C. A. \& Harackiewicz, J. M. (2018). Making learning personally meaningful: A new framework for relevance research. The Journal of Experimental Education, 86(1), 11-29. https://doi.org/10.1080/ 00220973.2017. 1380589

Saarni, C. (1999). The development of emotional competence. New York: Guilford. Schmidt, L. \& Poole, K. (2019). On the bifurcation of temperamental shyness: Development, adaptation, and neoteny. New Ideas in Psychology, 53, 13-21. doi: 10.1016/j.newideapsych.2018.04.003

Seider, S., Clark, S. \& Graves, D. (2019). The development of critical consciousness and its relation to academic achievement in adolescents of color. Child Development. DOI: 10.1111/cdev.13262

Seligman, M. (2002). Authentic happiness: Using the new positive psychology to realize your potential for lasting fulfilment. New York: Free Press.

Son, D. \& Padilla-Walker, L. (2019). Happy helpers: A multidimensional and mixed-method approach to prosocial behavior and Its effects on friendship quality, mental health, and well-being during adolescence. Journal of Happiness Studies. https://doi.org/10.1007/s10902-019-00154-2

Spence, S. H. \& Rapee, R. M. (2016). The etiology of social anxiety disorder: An evidence-based model. Behaviour Research and Therapy, 86, 50-67.

Surette, T. (2019). Too scared to teach: Secondary students' insights into educators silencing and stigmatizing gender and sexual diversity in public schools in Alberta, Canada. Contemporary Issues in Education, 14(2), 33-49. 
Taumoepeau, M., Sadeghi, S. \& Nobilo, A. (2019). Cross-cultural differences in children's theory of mind in Iran and New Zealand: The role of caregiver mental state talk. Cognitive Development, 51, 32-45.

Vracheva, V., Moussetis, R. \& Abu-Rahma, A. (2019). The mediational role of engagement in the relationship between curiosity and student development: A preliminary study. Journal of Happiness Studies. https://doi.org/10.1007/s10902019-00140-8

Woodcock, K., Cheung, C., Marx, D. \& Mandy, W. (2019). Social decision making in autistic adolescents: The role of theory of mind, executive functioning and emotion regulation. Journal of Autism and Developmental Disorders. https:// doi.org/10.1007/s10803-019-03975-5

Zavala, J. \& Kuhn, D. (2017). Solitary discourse is a productive activity. Psychological Science, 28(5), 578-586. https://doi.org/10.1177/0956797616689248 
